\title{
OBRAZY UMELCOV V TELEVÍZNYCH NARATÍVOCH NEŽNEJ REVOLÚCIE V ROKOCH 1990 - 1993
}

\author{
JANA DUDKOVÁ \\ Ústav divadelnej a filmovej vedy Centra vied o umení Slovenskej akadémie vied, Bratislava
}

\begin{abstract}
Abstrakt: Text je čiastkovým výstupom tematickej analýzy slovenskej televíznej produkcie raných devätdesiatych rokov 20. storočia, ktorej sa slovenská filmová veda doposial’ takmer nevenovala. Autorka štúdie skúma figúru umelca a vyčleňovanie humanitnej inteligencie v televíznej fikcii tesne po Novembri 1989, a to najmä v kontexte témy ohrozenia i skeptických naratívov spoločenskej zmeny.
\end{abstract}

Klúčové slová: televízny film, obraz umelca, humanitná inteligencia, ohrozenie

Figúra umelca, spisovatel’a, či v širšom zmysle predstavitel’a vysokoškolsky vzdelanej inteligencie je v slovenskej kultúre prinajmenšom od čias romantizmu vnímaná jednak vo funkcii prostredníka medzi mocou a l'udom, ale nezriedka aj vo funkcii do seba zahl'adenej elity, ktorej „tvorivý zápas“ ${ }^{\text {“1 }} \mathrm{s}$ rôznymi podobami ohrození je zmyslom takpovediac sám o sebe. V kontexte audiovizuálnej tvorby patrí koniec osemdesiatych a začiatok devätdesiatych rokov medzi tie obdobia, ked' sa v súvislosti s novou vlnou emancipácie kultúrnej inteligencie objavujú obidve spomínané polohy. Ak si odmyslíme niektoré rozprávky a adaptácie literárnych diel sociálneho realizmu (patriacich väčšinou do školských osnov), tak vo zvyšku hranej televíznej produkcie bude téma výlučnosti umelcov a vysokoškolsky vzdelanej elity zrejme dominovat'.

Hoci vyčerpávajúci kvantitatívny výskum témy humanitnej inteligencie, resp. figúry umelca v slovenskom filme nebol doposial' uskutočnený, je zrejmé, že ku koncu osemdesiatych rokov začína byt’ táto figúra čoraz zretel’nejšou. $\mathrm{V}$ kinematografii to reprezentuje napríklad Hanákovo nápadné preorientovanie sa na postavy z prostredia intelektuálov, umelcov či lekárov vo filme Súkromné životy (1990), načaté už výberom profesie protagonistky - zdravotnej sestry v Tichej radosti (1985), či výrazný nástup Miloslava Luthera v druhej polovici osemdesiatych rokov, ktorý tému úlohy intelektuála/umelca v spoločnosti dopĺňa na začiatku devätdesiatych rokov aj témou elít ako takých (Anjel milosrdenstva, 1993). No kým v kontexte kinematografie s postupom dekády prestáva byt” „intelektuálske“ zázemie postáv natol'ko dominantným, v kontexte televízneho filmu pretrváva aj roky po Nežnej revolúcii.

Hoci je zrejmé, že - ako tvrdí historik Michal Pullmann - „ani v Československu nevychádzal rozpad oficiálneho diskurzu zdola“ a prvými aktérmi tohto rozpadu bola inteligencia ,etablovaná ako na najvyšších miestach štátneho aparátu (Štrougal, Žák), tak aj na špecifických odborných fórach“" , môže byt prílišný dôraz na vyčle-

\footnotetext{
${ }^{1}$ Volne citované z anotácie filmu Čierny princ (réžia Pavol Haspra, 1989). In Archív RTVS.

${ }^{2}$ PULLMANN, Michal. Konec experimentu. Přstavba a pád komunismu v Československu. Praha : Scriptorium, 2011, s. 185. ISBN 978-80-87271-31-5. Preklad z českého jazyka Jana Dudková.
} 
ňovanie inteligencie problematický. Rozhodne ho totiž nemôžeme chápat' ako prirodzené zrkadlo jej aktuálnej sociálnej úlohy (ktorá je navyše premenlivá v čase) ${ }^{3}$, ale ovela viac ako komentár smerom k samotnému sociálnemu pol’u alebo poliam ${ }^{4}$. Navyše, dôraz na vyčleňovanie inteligencie môže nielen sugerovat' pocity ohrozenosti u aktérov, ktorí takéto diskurzy vytvárali ako svojrázne obrazy seba samých, ale môže pôsobit' kontrapoduktívne aj navonok. Najmä v kontexte solidarity a jednoty ${ }^{5}$, akú Československo zakúsilo koncom roku 1989, v prvých dňoch udalostí spontánne nazvaných revolúciou, predstavuje dlhodobé a na prelome osemdesiatych a devät'desiatych rokov $\mathrm{v}$ podstate kontinuálne uprednostňovanie prostredia humanitnej i technickej inteligencie, umelcov, lekárov či kultúrnych pracovníkov akýsi krok spät. Boli preto potrebné dlhé roky prehodnocovania a vnútornej kritiky, kým sa filmoví tvorcovia dostali k prvým sociálnym drámam (v polovici prvej dekády milénia) a kým si to o niekol'ko d’alších rokov všimla aj slovenská kritika. ${ }^{6}$

Ako to však bolo s kontextom televíznej tvorby, kde je vyčleňovanie elít omnoho výraznejšie a vzhl'adom na kvantitatívne omnoho bohatšiu produkciu aj omnoho frekventovanejšie než v kinematografii, ktorá začala obrat $\mathrm{k}$ inteligencii vel’mi rýchlo maskovat', napr. v bohémskych (Štefan Semjan) či záhradných (Martin Šulík) utópiách? Na túto otázku môže predkladaný text, ktorý vychádza z môjho rozsiahleho empirického výskumu hraných diel rôzneho typu z obdobia 1990 - 1993, odpovedat' len čiastočne. Jeho ciel’om bude mapovanie figúry intelektuála/umelca v hranej televíznej tvorbe v období medzi tzv. Nežnou revolúciou a vznikom samostatnej Slovenskej republiky, a to v kontexte meniacich sa naratívov samotnej revolúcie - od romantických až po skeptické či revolúciu popierajúce. Pochopitel'ne, ide len o záchytné body, ktoré som symbolicky vyčlenila práve rokmi 1990 - 1993. Tento interval totiž umožňuje položit' si aj otázku, do akej miery sa v dielach, ktoré boli pripravované pred Novembrom 1989, už mohli prejavovat’ rôzne formy priamej či nepriamej reflexie fenoménu revolúcie. Súčasne sa však dali zohl'adnit’ aj tie diela, v ktorých existovala pomerne vysoká pravdepodobnost', že zachytia kolektívne nálady súvisiace s premenami vnímania a sebavnímania inteligencie i umelcov (a ich úlohy v spoločnosti) v období rozdel'ovania spoločného štátu. Týmto spôsobom sa podarilo obmedzit’ mimoriadne rozsiahly korpus hraných televíznych programov bez toho, aby bolo nutné

\footnotetext{
${ }^{3}$ Analýzou sociálnej roly spisovatel’ov sa zaoberá napríklad monografia BARBORÍK, Vladimír - PASSIA, Radoslav. Spisovatel ako sociálna rola. Bratislava : VEDA, 2018. ISBN 978-80-224-1682-5.

${ }^{4} \mathrm{~K}$ pojmu pola pozri BOURDIEU, Pierre. Pravidla umění. Vznik a struktura literárního pole. Brno : Host, 2009. ISBN 978-80-7294-346-7.

${ }^{5}$ KRAPFL, James. Revolúcia s l’udskou tvárou. Politika, kultúra a spoločenstvo v Československu po 17. novembri 1989. Bratislava : Kalligram, 2009. Pozri najmä kapitolu Spolupatričnost', posvätnost' a zrod symbolického vesmíru, s. $55-100$.

${ }^{6}$ Marek Urban sa pokúsil ukázat', že masovejšie využívanie termínu „sociálna dráma“ medzi slovenskými filmovými kritikmi sa začalo až v roku 2012. Pozri URBAN, Marek. Identita autora. Príbehy, sociálne reprezentácie a naratívne Self v slovenskej kinematografii v rokoch 2012 - 2017. Bratislava : VEDA - Ústav divadelnej a filmovej vedy SAV, 2017, s. 74 - 77. ISBN 978-80-224-1631-3. Katarína Mišíková domnienky viacerých autorov, vrátane autorky tejto štúdie, o vykonštruovanosti termínu vo vzṫahu k slovenskému filmu presvedčivo vkladá do kontextu „ž́ánrovenia“ („genrification“) Ricka Altmana a poukazuje na synergiu kritikov a samotných tvorcov, ktorí žáner slovenskej sociálnej drámy tvorili. Sugeruje tak aj istú procesualitu, resp. neukončenost’ procesu. Pozri MIŠíKOVÁ, Katarína. Hladanie žánru v súčasnom slovenskom hranom filme. In Nový slovenský film. Produkčné, estetické, distribučné a kritické východiská (Eds. Katarína Mišíková a Mária Ferenčuhová). Bratislava : Vysoká škola múzických umení, 2015, s. 9 - 36. ISBN 978-80-89439-91-1.
} 
sa rozhodnút len pre jeden typ programov. ${ }^{7}$ Ked’že sa totiž rovnaké témy opakovali naprieč žánrami, zvolila som radšej časové než žánrové či typologické obmedzenie a do výskumu som zahrnula nielen inscenácie a adaptácie divadelných hier, ale napr. aj prevzaté divadelné predstavenia. Tie nezriedka zapíňali $\mathrm{v}$ televíznej dramaturgii medzery, ktoré nestíhala pokryṫ časovo náročnejšia či myšlienkovo nedostatočne pružná pôvodná televízna tvorba. ${ }^{8}$

Na základe preskúmania väčšiny hraných relácií vyrobených v rokoch 1990 - 1993 som sa rozhodla rozčlenit text do troch samostatných častí. V tejto štúdii predkladám prostrednú z nich, zameranú na vyčleňovanie figúry umelcov v kontexte témy ohrozenia i skeptických náhl'adov na možnost’ či aktuálnu podobu spoločenskej zmeny. Ďalšie dve sa budú venovat elitárstvu ako dominantnému prvku romantických naratívov spoločenskej zmeny a otázke autoreflexie televíznych pracovníkov vo vybraných filmoch, ktoré sa priamo dotýkajú televíznych profesií.

\section{Vyčleňovanie elít v spoločnosti bez zmeny}

Napätie medzi myšlienkou celospoločenského konsenzu a predstavou klúčovej úlohy inteligencie $\mathrm{v}$ jeho spustení bolo možné sledovat' už v prvých dňoch po 17. novembri 1989. Ide často o nevedomé a následne chvatne korigované náznaky. James Krapfl napríklad uvádza prvé vyhlásenie Verejnosti proti násiliu k verejnosti, ktoré podla neho „umožňovalo výklad, že ide o hnutie iba ,kultúrnej a vedeckej verejnosti'“9 . V kontexte televíznej tvorby je možné postrehnút podobné napätie, ktoré zrejme fungovalo aj v kontexte samotného tvorivého procesu a jeho fáz. Je totiž možné ho vystopovat' $\mathrm{v}$ diskrepanciách na úrovni dramaturgie jednotlivých diel, ale napríklad aj na úrovni nesúladu medzi výslednou podobou konkrétnych filmov a anotáciami, pod ktorými sú registrované v archíve inštitúcie. Podrobnejšia analýza tvorivého procesu by zrejme odhalila aj d’alšie úrovne, zatial' sa však obmedzíme na tieto dve, ktoré sa dajú dobre doložit archívnymi materiálmi a v oboch prípadoch ich možno chápat’ ako špecifické problémy televíznej dramaturgie. ${ }^{10}$

${ }^{7} \mathrm{Na}$ základe údajov z elektronickej databázy RTVS, ktoré mi sprístupnila pracovníčka Archívu RTVS Lenka Krnáčová, je možné vypočítat', že relácií dramatickej tvorby, ktoré by približne mohli zodpovedat definícii hraného programu (teda s výnimkou animovaných večerníčkov či pásiem poézie, ktoré som z výskumu hned’ v úvode vylúčila), má roky výroby 1990 - 1993 vyše 270 . Do uvedených čísiel sú síce započítané aj časti dvojdielnych či trojdielnych filmov a cyklov, príp. niekolko seriálov (napr. Štúrovci, réžia Peter Mikulík, 1991; Otecko sa mi nepáči, réžia Zoro Laurinc, 1991; Čo trápi Tomáša, réžia L'ubomír Kocka, 1990 a pod.), väčšinou však ide najmä o jednodielne programy. Presné čísla neuvádzam najmä z dôvodu tažšieho určovania typológie jednotlivých relácií, ked’že databáza nedisponuje všetkými potrebnými údajmi.

${ }^{8} \mathrm{~V}$ tomto texte som sa z podobných dôvodov rozhodla nerozdelovat hranú produkciu podla metráže, ani podla toho, či šlo o filmy nakrútené na klasický filmový materiál, video-filmy alebo tzv. inscenácie. V priebehu výskumu sa totiž ukázalo, že v samotnom prostredí televízie chýba jednotná terminológia i spôsob spracúvania informácií, a teda na základe krátkych anotácií v elektronickej databáze RTVS často nebolo možné určit typ jednotlivých programov ani typ materiálu, na ktorý boli nakrútené (údaje o materiály sú napr. uvedené vo Filmových ročenkách Slovenského filmového ústavu, tie však uvádzajú len zlomok filmov, vyrobených v televízii).

${ }^{9}$ KRAPFL, James. Revolúcia s l'udskou tvárou, s. 157 - 158

${ }^{10}$ Vzhl'adom na to, že RTVS v súčasnosti nedisponuje dramaturgickými plánmi či mnohými písomnými dokladmi týkajúcimi sa prípravy programov po páde režimu, a že metóda oral history by takisto nemusela priniest̉ uspokojujúce odpovede, nekladiem si za ciel' pátranie po dôvodoch tohto napätia, iba ho $\mathrm{v}$ dostupných prameňoch registrujem. Mojím ciel'om preto nebolo ani podrobné mapovanie histórie dramaturgických či produkčných rozhodnutí, vývoja filmov a pod. Vychádzala som prevažne z porovnávania 
Ako príklad diskrepancie na úrovni dramaturgie, presnejšie, v kontexte nekoherentných, nezmotivovaných či nedôveryhodných scenáristických riešení, môžeme uviest’ záver filmu Rozprávka o tichej krajine (réžia Martin Kákoš, 1990). V ňom prepukne ludová vzbura voči alegorickej postave Ticha, ktoré terorizuje krajinu, no motivácie k vzbure sú dvojaké. Na jednej strane ide o pomerne spontánnu vzburu davov, na druhej strane sa náhle vráti z vyhnanstva skupina kočovných hercov, ktorá ludí predtým neúspešne motivovala k odvahe. Definitívne odbúranie strachu tak môže byt' napokon asociované práve s divadelnou skupinou, ktorá na l'udí volá: „Nech všetci počujú, čo si skutočne myslíte! Preč s Tichom!“. Rozprávka o tichej krajine je v ponovembrovej hranej tvorbe pomerne výnimočným filmom, ked’že priamo pripomína mýtizovanú rolu divadelníkov v Nežnej revolúcii. Napriek tomu je v závere zároveň vytvorený dojem, že vzbura vychádza zdola. Doslova tak dochádza k akémusi súboju o pravdu medzi širokými davmi a divadelníkmi.

Rozprávka o tichej krajine patrí do širokej skupiny diel sugerujúcich vyčleňovanie umelcov, vedcov, intelektuálov, či dokonca len vysokoškolsky vzdelaných ludí od zvyšku spoločnosti. Napriek tomu, že viac než s obrazom dobových elít pracuje s obrazom potulných komediantov a l'udí z okraja spoločnosti, ich profesia odkazuje aj $\mathrm{k}$ súčasným úlohám divadla. Tendencia vyčleňovat' umelcov/inteligenciu dominuje v skupine diel zo súčasnosti, no často sa objavuje aj pri látkach z minulosti. Vo všeobecnosti ju teda možno chápat’ ako príznakovú. Inteligencia a umelci totiž v čase prestavby znova získali aureolu reálneho či potenciálneho bojovníka s autoritatívnou mocou. V slovenskej televíznej tvorbe tak môžeme registrovat' relatívnu koexistenciu romantických naratívov, zväčša však v rozprávkach alebo aspoň filmoch vyrobených $\mathrm{v}$ rámci redakcií venujúcich sa tvorbe pre deti, a naratívov, ktoré sa na možnost’ alebo realitu politickej zmeny pozerajú skepticky. Adaptácie a inscenácie overených predlôh sú obvykle menej tézovité než pokusy o pôvodné diela či snahy importovat’ predlohy z krajín tzv. západného bloku. Výber látok často zdôrazňuje situácie, v ktorých umelec/intelektuál čelí malosti či primitivizmu prostredia (napr. inscenácia Útrapy z rozumu, réžia Miloš Pietor st., 1990; pôvodné televízne filmy Papierový drak, réžia Igor Kováč, 1992; Lákavé stredisko rýchleho vytriezvenia, réžia Juraj Takáč, 1992). V d’alších filmoch sa hrdina pod tlakom totalitnej alebo imperiálnej moci dopúšta tragických zlyhaní (Lorenzaccio, réžia Miloslav Luther, 1991; Výstrel na Bonaparta, réžia Ján Zeman, 1992), alebo dokonca zrady na blížnych (Piata pečat', réžia Martin Kákoš, 1990; Príbeh Mateja Hóza, réžia Peter Mikulík, 1993), zvádza márne boje o slobodu konat' podl'a vlastného morálneho cítenia (Profesor Bernhardi, réžia Vladimír Strnisko, 1993), prípadne ho spoločnost’ z rôznych dôvodov označí za blázna (klasické predlohy Útrapy z rozumu či Pavilón číslo 6, réžia Ernest Stredňanský, 1992; filmy spracúvajúce súčasné látky, napr. tému jedinca, ktorý sa nevie prispôsobit podnikatel'skému duchu doby v snímke Lákavé stredisko rýchleho vytriezvenia). Niekedy hrdina čelí vlastnému previneniu i neludskej moci prostredníctvom umenia (takúto pointu o zmysle El Grecových obrazov sa snaží vsugerovat adaptácia Vestdijkovej predlohy Piata pečat'), inokedy márnost' ušlachtilých myšlienok potvrdí smrtou v súboji (Zurvalec, réžia Vladimír Strnisko, 1993, podl'a pôvodne divadelnej adaptácie Turgenevovej poviedky od Antonína Mášu).

empirického výskumu televíznych hraných programov s tematickou analýzou anotácií týchto programov v Archíve RTVS. 
Pri takýchto témach môžeme popri koexistencii romantických a skeptických náhl'adov na spoločenskú zmenu sledovat' aj koexistenciu relatívne suverénnych úvah o spoločenskej úlohe intelektuála s tými, v ktorých - ako v Rozprávke o tichej krajine - dochádza k akémusi súboju o pravdu, k snahe priznat úlohu širokých más, ale zároveň sa takmer úzkostlivo projektovat’ do exkluzívnej skupiny ako klúčového iniciátora zmeny. Elity v televíznych filmoch môžu stelesňovat nádeje na celospoločenskú zmenu a pri tom predpokladat' solidaritu so slabými (napr. vo filmoch Dido, réžia Dušan Rapoš, 1991; Zrkadlo, réžia Jozef Bednárik, 1992). Častejšie sú však, bez ohl’adu na výber historickej doby, prezentované ako uzavreté do seba ${ }^{11}$, niekedy plné potenciálneho pohŕdania ostatnými ${ }^{12}$, ale aj morálneho sebaspytovania a prehodnocovania vlastnej spoločenskej roly. Mimo romantických naratívov zmeny je táto podoba častejšia, obraz ohrozenia nároku na pravdu je v nich priamo priznávaný. Napríklad v Konečnej doline (réžia Jozef Banyák, 1990) bojuje idealistický architekt s predstavami dedinčanov i cynizmom podnikatel'skej sféry, no nakoniec sa musí svojich architektonických návrhov vzdat. Pravdu humanizmu pred totalitnými režimami zase obhajujú maliar El Greco stojaci proti španielskej inkvizícii (Piata pečat') i kňazi čeliaci vzmáhajúcemu sa nacizmu (A kamene budú kričat', réžia Roman Polák, 1990). Útek od totality nacizmu k bezbrehej, až primitívnej hollywoodskej komercii vyskúšajú na vlastnej koži postavy hry Christophera Hamptona o fiktívnom exile Ödöna von Horvátha v Spojených štátoch amerických, kde sa stretáva s bratmi Mannovcami či Bertoltom Brechtom (Rozprávky z Hollywoodu, réžia Stanislav Párnický, 1992). ${ }^{13} \mathrm{~V}$ Lákavom stredisku rýchleho vytriezvenia sa nezamestnaný doktor filozofie pokúša podnikat' v gastronómii, no nevie sa zorientovat’ v atmosfére neodbornosti a rodinkárstva (zobrazeného napríklad v scéne, ked’ mu je predstavený celý regiment remeselníkov prepojených tým istým priezviskom) a končí v blázinci ešte skôr, než sa mu podarí zrekonštruovat' lacno kúpený priestor.

Zaujatie inteligenciou, najmä tou kultúrnou, je zretelné aj z anotácií, pod ktorými sú jednotlivé filmy zaregistrované v Archíve Slovenskej televízie. ${ }^{14}$ Ide o neautorizované krátke texty, z ktorých mnohé zrejme vznikali už pri literárnej či dramaturgickej príprave. Anotácie nemajú jednotnú formu ani štruktúru, niekedy dokonca chýbajú. Rozmanitý je aj ich rozsah: od niekol'koslovných cez niekol'ko vetné charakteristiky až po vyčerpávajúce scénosledy ${ }^{15}$. Často ich charakterizuje terminologický zmätok,

\footnotetext{
${ }^{11}$ Napríklad trojdielna inscenácia Dobrodinec (réžia Ján Zeman, 1990) na ploche vyše troch a pol hodín rozpráva o rodine univerzitného profesora a učitel'ky hudby, ktorá sa vo volnom čase venuje aj mal'be. Už v úvode sa dozvedáme o talente a pozitívnom vztahu $\mathrm{k}$ umeniu u ich troch odrastených detí, pričom dramatický konflikt vzniká po stretnutí rodiny s majetným právnikom, ktorý rodine na základe svojich konexií začne prehnane a z nejasných dôvodov pomáhat’ k ešte vyššiemu spoločenskému postupu a pohodliu.

${ }^{12}$ Motív pohŕdania menej vzdelanou populáciou je výraznejšie tematizovaný napr. vo videofilme Hlavne, ked’ sa radi máme (réžia Jozef Banyák, 1989), hoci je pravda, že tu sa dostáva najmä do kontextu stereotypne zobrazenej ženskej túžby po postupe na spoločenskom rebríčku.

${ }^{13}$ Dramatik a spisovatel Ödön von Horváth zahynul pri páde stromu počas búrky na Champs-Élyséees v roku 1938. Fiktívny príbeh jeho exilu je síce rámcovaný nehodou pri búrke, no rozprávanie sa začína vo chvíli, ked’ von Horvath (Emil Horváth ml.) vstane z lôžka a v úlohe žoviálneho konferenciera nás sprevádza svojimi „zážitkami“ z vojnových i povojnových Spojených štátov amerických.

${ }^{14} \mathrm{~V}$ texte používam spojenie "Archív Slovenskej televízie“, pokial' sa jedná o dokumenty predchádzajúce zlúčeniu Slovenskej televízie a Slovenského rozhlasu k 1. 1. 2011. Po tomto dátume sa inštitúcia premenovala na Rozhlas a televíziu Slovenska (v skratke RTVS), zhodne s tým používam „Archív RTVS“ pre dokumenty vytvorené po tomto dátume.

${ }^{15}$ Tie sú používané len výnimočne, ked’ treba zdôraznit, že relácia má prevažne asociatívny charakter.
} 
ked’že v nich nie sú jasne stanovené hranice medzi adaptáciou, inscenáciou, videofilmom a pôvodným televíznym filmom. Napriek tejto nejednotnosti však fungujú ako užitočný zdroj informácií o sebavnímaní televíznych pracovníkov. Tak ako môže absencia jednotnej štruktúry a terminologického konsenzu svedčit’ o akomsi spola zámernom tvorivom chaose, tak sa z nich dá vyčítat’ aj zámerné či nezámerné tematizovanie výlučnosti inteligencie a kultúrnych elít. V mnohých z nich sa totiž pojmy ako spisovatel', umelec či vysokoškolské vzdelanie prezentujú v kontextoch, ktoré evokujú nielen pozitívne hodnotenie, ale aj vnútorné vymedzovanie sa voči nehodným členom skupiny i spoločnosti. Texty anotácií pritom nezriedka deformujú vyznenie samotných anotovaných diel. Napríklad adaptácia komédie Ivana Vazova Súboj (réžia Peter Opálený, 1990) je charakterizovaná ako „príbeh bezvýznamného spisovatela a bezvýznamného právnika"16, hoci samotnú hru i inscenáciu môžeme vnímat’ ako komunálnu satiru so širšou platnostou. Tá mieri skôr k obrazu štandardného správania inteligencie: bulharský autor v hre sugeruje zbabelost’ a malost' svojho národa a v závere naznačuje, že príbeh dvoch hlavných postáv, ktoré sa nechajú nahovorit’ na súboj a potom sa mu v strachu vyhýbajú falošnými udaniami na seba samých, je jedným z mnohých. V konečnom dôsledku sa ich príbeh dokonca dostáva do súvislosti s neschopnostou polície vypátrat’ atentátnika, ktorý chce zabit ministra: ukazuje sa, že falošné udania súvisiace s atentátom sú bežnou stratégiou, ako sa vyhnút následkom smelých gest.

Kým v prípade Súboja ide o akýsi pokus dodatočne vymedzit skupinu nehodných („,bezvýznamných“) medzi hodnými, inokedy sa pri postavách podobne anonymných spisovatel'ov operuje skôr so sugesciou pozitívnej výlučnosti spisovatel'ského stavu. Tak je to napríklad pri dvojdielnom filme Čierny princ (réžia Pavol Haspra, 1989) ${ }^{17}$ „o osudoch l'úbostného citu starnúceho spisovatel’a, pre ktorého je umenie jediným zmyslom života, osudom i kliatbou“, a v ktorom sa odzrkadl'uje "tvorivý l’udský zápas, hladanie životnej múdrosti a pravdy“. ${ }^{18}$ Paradoxne, uvedené floskuly zodpovedajú len jednej z postáv. Inscenáciu je v konečnom dôsledku možné chápat’ ako síce zdĺhavé, ale vcelku pozoruhodné obvinenie pragmatizmu a neúprimnosti umelcov. Adaptácia predlohy Iris Murdochovej výborne korešponduje s rétorikou prestavby, ktorá čoraz častejšie upozorňuje na stratu úprimnosti, lásky a dôvery v medzil’udských vztahoch. ${ }^{19}$ Zaoberá sa rekonštrukciou vzt’ahov nevel'mi významného spisovatel’a a jeho elitných priatel'ov, vrátane slávneho kolegu, z ktorého vraždy je nakoniec obvinený. Príbeh je vyrozprávaný ako retrospektíva z pozície nepochopitelne rezignovaného odsúdenca (Štefan Kvietik), ktorý sa odmieta bránitł. Hned' v úvode však minulé udalosti kontrastujú s výpoved’ami svedkov na súde. Postupne

\footnotetext{
Práve takéto prípady však podčiarkujú štylistickú a štruktúrnu nejednotnost’ anotácií. Napríklad k poetickému filmu Výpravca holubov (réžia Samuel Ivaška, 1991) je v elektronickej databáze RTVS priložený popri dvojslovnej charakteristike druhu filmu len vyčerpávajúci scénosled. Podobne to platí i pre kombinovanú reláciu Piatky-sviatky (réžia Anton Majerčík, 1990), kde sa anotácia začína určením základnej témy, po ňom však nasleduje pomerne podrobný popis základných scén filmu.

${ }^{16}$ Anotácia v elektronickej databáze RTVS.

${ }^{17}$ Výnimočne do súboru analyzovaných diel začleňujem aj niektoré z tých, ktoré boli vyrobené pred Novembrom 1989.

${ }^{18}$ Anotácia v elektronickej databáze RTVS.

${ }^{19} \mathrm{~V}$ zásade ide o podobné témy, aké nastoluje aj postmoderný diskurz. Rozdiel je v tom, že postmoderný postoj k uvedeným hodnotám je zväčša cynický alebo ironický, kým diskurz prestavby ešte operuje s tragickými naratívmi dezilúzie a straty.
} 
sa tak odhal'ujú manipulačné hry, do ktorých je budúci odsúdenec zavliekaný a na základe ktorých je neskôr falošne obvinený. Výsledkom takejto konfrontácie výpovedí na súde s rekonštrukciou minulosti je sugescia morálneho vítazstva odsúdenca i jeho špecifického, nepragmatického vztahu k umeniu, ktoré ho síce naučilo pozorovat', ale ked' treba, tak aj mlčat' - v živote i v umení.

Z uvedených dvoch príkladov môžeme vidiet', na akú vratkú a nejednotnú pôdu vstupovali na prelome osemdesiatych a devätdesiatych rokov filmy o elitách. $\mathrm{Na}$ jednej strane stojí satirická hra o neuskutočnenom súboji, vypovedajúca o zbabelosti intelektuálnych elít v čase politickej nestability (obraz Bulharska pred 1. svetovou vojnou mal pripomenút aj nešváry neskorosocialistickej inteligencie), ktorá si v čase spoločenskej zmeny vyžiadala ospravedlnenie $\mathrm{v}$ podobe údajného fokusu na dvojicu „bezvýznamných“ predstavitel’ov svojich profesií. Na druhej strane, skorší film Čierny princ ešte maskoval svoj apel na morálne cítenie ako štandardný príbeh „tvorivého zápasu“ umelca v kontexte odmietania lží i pragmatizmu elít na konci osemdesiatych rokov.

Emancipácia humanitnej inteligencie v Československu začala byt’ výraznejšia už v druhej polovici osemdesiatych rokov. Musela sa však popasovat' s nesúladom medzi ohlásením prestavby v ZSSR a strachom československých elít prihlásit sa $\mathrm{k}$ nej. ${ }^{20}$ Súčasne s emancipáciou silneli aj vnútro-profesijné delenia. Podla Michala Pullmanna, zárukou, „že kritické hlasy nepovedú k spoločenskej destabilizácii, mala byt istá miera inštitucionálnej (,zväzovej') autonómie a pomerne prísne kritériá výberu kádrov aj ich kariérneho postupu. Tým sa však paradoxne prehlbovala neistota aktérov ohl'adne udržatel'nosti daného usporiadania." ${ }^{21}$ Neistota, inými slovami pocity ohrozenia, boli v období socializmu obvyklé. Dôležité je ale uvedomit’ si, že aj pri nich môže platit ekvivalencia medzi „nebezpečným“ a „nečistým“, ako o nej píše etnografka Mary Douglas. Vymedzovanie „čistého“ totiž zvyčajne súvisí so snahou ochránit’ sa pred tým, čo dané spoločenstvo vníma ako nebezpečné (pochopitelne, to sa v kolektívnej imaginácii následne vníma ako „znečistené“). ${ }^{22}$ Práve s týmto druhom vymedzovania a vypudzovania „nečistého" súvisia vyššie uvedené príklady zdôrazňovania spisovatel'ského povolania ako pozitívnej hodnoty, ktorú treba očistit' od prípadných „nečistých“ prvkov alebo nehodných členov. Uvedené príklady ukazujú, že ani silnejúce kritické hlasy v druhej polovici osemdesiatych rokoch neznamenali odstránenie neistôt ohladom vlastnej pozície v spoločnosti a jej akceptácie rôznymi adresátmi, od potenciálnych „cenzorov" na rôznych úrovniach až po širšiu verejnost', ktorej boli jednotlivé televízne programy určené.

Ďalším, značne odlišným príkladom napätia, ktoré môžeme vnímat’ medzi anotáciou a výsledným filmom, je film Tajomstvá pod viečkami (réžia Juraj Nvota, 1990). Hlavná redakcia programov pre deti a mládež ho vo svojich plánoch na rok 1990 registruje už v októbri 1989, premiéru mal 27. 4. 1990. ${ }^{23}$ Podl’a anotácie má íst' o pô-

${ }^{20}$ Porov. PULLMANN, Michal. Konec experimentu; tiež SVOBODA, Libor. Přestavba z historického hlediska. In KOPAL, Petr a kol. Film a dějiny 5. Perestrojka / přestavba. Praha : Václav Žák - Casablanca a Ústav pro výzkum totalitných režimů, 2016, s. 60 - 84. ISBN 978-80-87292-33-4.

${ }^{21}$ PULLMANN, Michal. Konec experimentu, s. 115.

${ }^{22}$ DOUGLAS, Mary. Purity and Danger. An Analysis of Concepts of Pollution and Taboo. London - New York : Routledge \& Kegan Paul Ltd., 1966. ISBN 0-7100-1299-3.

${ }^{23}$ Pozri Ideovo-tematický plán na rok 1990/1991. Bratislava : Československá televízia Bratislava - Hlavná redakcia vysielania pre deti a mládež, október 1989, s. 17. 
vodnú televíznu inscenáciu „o učnici Irme, ktorá konfrontuje svoje ideálne predstavy $\mathrm{s}$ neraz odlišnou každodennou realitou“ ${ }^{\prime 24}$. Za týmito slovami sa naozaj skrýva film o učnici, avšak jeho dominantnou témou je vzṫah neskorosocialistickej spoločnosti ku knihám - čo napokon pôvodná anotácia uvedená v dramaturgickom pláne aj priznáva ${ }^{25}$, hoci neskôr bol film registrovaný pod anotáciou, ktorá zameranie na knižnú kultúru zamlčiava.

Snaha viac sa venovat' robotníckej triede sa v dramaturgických plánoch Československej televízie Bratislava objavuje ešte v polovici osemdesiatych rokov. Tvorivá skupina pre mládež sa napríklad mala orientovat’ „na súčasnost’ - na vytváranie príkladných typov súčasného mladého hrdinu - najmä z robotníckeho, učňovského, pol'nohospodárskeho prostredia, ako i z prostredia študentov, mladých vedeckých pracovníkov a inteligencie “26. Na konci dekády však táto požiadavka nebola chápaná vel'mi vážne, takže aj v prípade filmu Tajomstvá pod viečkami mohlo už pri literárnej príprave dôjst' k posunom významov. Preto je hned' v prvom zábere filmu naznačený špeciálny status Irmy: hŕba kníh, pod nimi zasnívaná tvár dievčata dívajúceho sa z okna. Takmer všetky postavy sú priamo prepojené s motívom kníh: pracujú s nimi, vyučujú literatúru, patria, prípadne by chceli patrit’ do spisovatel'skej obce. Aj samotná Irma je učnicou iba $\mathrm{v}$ tom zmysle, že praxuje $\mathrm{v}$ kníhkupectve a navštevuje knihovnícku školu. Scenár Dušana Dušeka tak variuje jedno z jeho trvalých zameraní, ktorým je fokus na l’udí „od literatúry a filmu“27, ale len preto, aby na príklade profesií a záujmov prepojených s knihami ukázal fungovanie neskorosocialistickej ekonomiky i spoločnosti. V anotácii avizovaný stret ideálov učnice s neveselou realitou znamená najmä stret s podpultovým predajom, plnením plánov a súčasne nedostatkom tovaru, s egocentrizmom umelcov neschopných prijat kritiku, s ad absurdum dovedenou byrokraciou a falošným autoritárstvom štátneho školstva. (Ide o d’alší zo série filmov, v ktorých vystupuje jednoznačne nesympatická postava tyranskej učitel'ky, ktorá tu priamo trestá žiakov za ich názory. ${ }^{28}$ ) Zameranie na knihy v zmysle spojiva medzi postavami vytvára množstvo situácií na hranici pravdepodobnosti a vtipu. Jedna z epizódnych postáv, takpovediac žena z luudu (Katarína Kolníková), si napríklad pravidelne berie dovolenky „od rodiny“, aby sa výmenou čerstvého mäsa za knihy mohla venovat’ svojej vášni.

Popri už zmienených diskrepanciách na úrovni dramaturgie vybraných filmov alebo ich zavádzajúcich opisov v anotáciách je d’alším symptómom neistoty tvorivých pracovníkov televízie aj nápadný dôraz na izoláciu intelektuálnych elít. Nie

\footnotetext{
${ }^{24}$ Údaje k relácii, elektronická databáza RTVS.

${ }^{25}$ Celkovo je táto pôvodná anotácia omnoho bližšia pravde: „Príbeh učnice-predavačky Irmy, ktorá $\mathrm{v}$ zaujímavom prostredí kníhkupectva hladá pravdu, ktorú opisujú v knihách (...). Kritický pohlad na milovníkov kníh, ktorí zbierajú knihy ako nové šaty, bez toho, aby si z nich zobrali múdrosṫ a ponaučenie." Pozri Ideovo-tematický plán na rok 1990/1991, s. 17.

${ }^{26}$ Ideovo-tematický plán (II. verzia) 1986/1987. Bratislava : Československá televízia Bratislava - Hlavná redakcia vysielania pre deti a mládež, júl 1985, s. 4.

${ }^{27}$ PASSIA, Radoslav - TARANENKOVÁ, Ivana (eds.). Hladanie súčasnosti. Slovenská literatúra na začiatku 21. storočia. Bratislava : Literárne informačné centrum, 2014, s. 70 - 71. ISBN 978-80-8119-085-8.

${ }^{28}$ Učitelka literatúry napríklad zakazuje žiakom vlastné interpretácie diel a žiada reprodukciu hesiel z Encyklopédie slovenských spisovatel'ov, ktoré prezentuje ako svoje názory. Na rozdiel od stereotypov pokrytectva a rigidity učitelov použitých v iných dobových filmoch (Štyri pät'ky, réžia Kvetoslav Hečko, 1992; Kto hodil kameňom?, réžia Zdeno Dř́novský, 1992; Papierový drak) sú však postoje učitel'ky tentoraz prezentované $\mathrm{s}$ vtipom a citom pre absurditu.
} 
vždy totiž obraz izolácie sprevádza (auto)irónia tak, ako je to v zmienených Tajomstvách za viečkami, kde scenár zámerne pracuje s až nepravdepodobnou segregáciou ludí prepojených s knihami a využíva ju na to, aby jednou ranou spochybnil moderné stereotypy o elite národa i socialistické stereotypy o zdravom jadre spoločnosti. Naproti tomu, v niektorých prípadoch je téma izolácie domácich elít zamaskovaná „exotickými“ adaptáciami diel spoza železnej opony, ked’ na scénu prichádza inteligencia z vyšších spoločenských tried tzv. prvého sveta - elity s dobrým prístupom ku vzdelaniu, pozitívnym vztahom k umeniu a neraz snahou pomáhat’ slabším (Čierny princ, Dobrodinec).

Vd’aka zvýšenej miere sebareflexie tvorivých umeleckých profesií vznikali ale i diela, ktoré priamo odkazujú k absurdite vyčleňovania. Príkladom je inscenácia divadelnej hry Mačka domáca sovietskych autorov Vladimíra Vojnoviča a Grigorija Gorina (réžia Milan Lasica, 1992). Segregácia spisovatel'skej komunity je tu zdôraznená napríklad faktom, že väčšina postáv obýva rovnakú bytovku, a tak ich vzájomné vzt’ahy, vnútorné rozčlenenia a hierarchia fungujú ako zdroj vtipov a - podobne ako v Tajomstvách pod viečkami - aj ako zrkadlo zvyšku spoločnosti, s ktorým však sebou zaujatí spisovatelia prichádzajú len do minimálneho kontaktu (napr. prostredníctvom listov od prípadných fanúšikov). Úzke zameranie je zároveň prejavom irónie namierenej $\mathrm{k}$ vyšším štátnym kruhom a ohlasujúcej typické témy prestavby. Rozprávačom príhod je totiž spisovatel-disident, ktorý hned' v úvode ozrejmuje svoje úzke zameranie ako ekonomické a etické riešenie, zabraňujúce plytvaniu i zbytočnému cestovaniu: „Študujte život tam kde žijete, je to ovel’a produktívnejšie a lacnejšie. Napríklad náš dom... žijú tu inžinieri l’udských duší, členovia bytového stavebného družstva, spisovatel’ metropoly, známi, málo známi, neznámi. “29 Napriek izolácii od všetkých ostatných profesijných a sociálnych skupín ide o pomerne rozmanitú vzor$\mathrm{ku}$, priliehavo ilustrujúcu tézu, že rigidnost’ socialistického usporiadania neviedla k nivelizácii spoločnosti, ale k vnútorným segregáciám a neistotám v rámci skupín.

Hoci je dej Mačky domácej situovaný na začiatok osemdesiatych rokov ${ }^{30}$, satirický obraz neskorosocialistickej society sovietskych spisovatel'ov obsahuje aj ozveny Bulgakovovho výsmechu stalinskej byrokracie a hierarchizácie (napríklad v románe Majster a Margaréta), na čo nevdojak upozorní jedna z postáv nenápadným vzývaním jeho mena. Základný konflikt tejto vydarenej satiry ${ }^{31}$ je pritom mimoriadne banálny: vzniká, ked' jedného zo spisovatel'ov, užívajúceho si zdanlivo pevné miesto v profesijnej hierarchii, pošle manželka prevziat’ si centrálne pridel'ovanú čapicu. ${ }^{32}$ Názov snímky odkazuje k materiálu (druhu zvierat’a), z ktorého má byt čapica vyrobená. Podla toho, v akej baranici sa postavy objavujú, sa odhal'uje ich skutočné hierarchické postavenie v komunite i snahy o jeho zamaskovanie pred závistlivcami. Jednoduché

${ }^{29}$ Citát z filmu.

${ }^{30}$ Pozri anotáciu v elektronickej databáze RTVS.

${ }^{31}$ Popri vtipnej predlohe je inscenácia i výborne obsadená, pričom samostatné významy vznikajú aj na základe faktu, že režisér (Milan Lasica) i viacerí z interpretov (Július Satinský, Marián Labuda, Martin Huba, Stanislav Dančiak, František Kovár) začínali tvorit’ v uvolnenej atmosfére šest’desiatych rokov, no neskôr lavírovali medzi oficiálnou a neoficiálnou kultúrou, prípadne sa výraznejšie angažovali pri Nežnej revolúcii či v rôznych spoločensky angažovaných televíznych projektoch.

${ }^{32}$ Spisovatel' (Marián Labuda) to najprv odmieta, odvolávajúc sa práve na Bulgakova, ktorý vraj hovoril: „Nič od nich nežiadaj, sami prídu, sami dajú." "Bulgakov bol šlachtic. Možno mal čiapku z bobra", oponuje mu manželka (Božidara Turzonovová). 
vizuálne znaky takto pomáhajú priviest’ ad absurdum aj princíp vyčleňovania ako taký.

V mnohých prípadoch je však záujem o tvorivé profesie naturalizovaný. Typickým príkladom naturalizácie je dvojdielny mládežnícky film Jediná (réžia Anton Majerčík, 1991), ktorý sa nevenuje len téme dospievania, ale nenápadne sugeruje i ukotvenie protagonistky $\mathrm{v}$ exkluzívnom rodinnom prostredí, takže dôraz na talent a umelecké zameranie dospievajúceho dievčat’a nie sú v takomto kontexte prekvapivé. Klepot písacieho stroja prezrádza profesie Ol'giných rodičov, architektonicky netradične riešený byt Olginej tety, plný umeleckých obrazov, sugeruje tvorivé profesie jeho obyvatelov. Obrazy na stenách sú popri záberoch na písacie stroje totiž d’alším frekventovaným spôsobom ako poukázat’ na to, že postava patrí do špeciálnej „kasty“. Nájdeme ich napríklad i v úvode filmu Dve Anny (réžia Igor Ciel, 1989) - následne nás už neprekvapí, že hrdinka filmu pracuje v nemenovanej redakcii, hoci jej povolanie nemá v kontexte deja žiaden význam, ked’že ju spoznávame krátko pred nehodou, ktorá ju pripúta na invalidný vozík.

Uvedené príklady ukazujú, že ide o akési žánrové obrázky: niektoré filmy prostredníctvom rekvizít hned' v úvode vymedzujú teritórium, na ktorom sa budú pohybovat', d’alšie zase celkom nevedomky prezrádzajú uzatváranie profesijných skupín podiel'ajúcich sa na vzniku filmov pred ostatnými spoločenskými vrstvami. Popri jednoduchej vizuálnej signalizácii však môžu mnohé príklady dobovej produkcie z dnešného hl'adiska priam iritovat’ snahou o verbálne vyjadrenú exkluzivitu. Najmä v pôvodnej tvorbe sa až toporne tematizujú tituly jednotlivých postáv či ich povolania, nezriedka práve so zámerom dôrazne ich vyčlenit’ od zvyšku spoločnosti. Oslovovanie postáv vysokoškolskými titulmi v Hlavne, ked’ sa radi máme (réžia Jozef Banyák, 1989), narážky na spor ušlachtilých ciel’ov architektúry a podnikatel'skej sféry v úvode Konečnej doliny, nedorozumenia okolo titulu doktora filozofie v Lákavom stredisku rýchleho vytriezvenia, to všetko môžeme chápat’ ako reakcie na tému ohrozenia inteligencie nevzdelanou väčšinou. Na rozdiel od látok z minulosti, kde je vzdelanie naturalizovanou výsadou bohatých, sa bazírovanie na vysokoškolskom vzdelaní najmä v pôvodných dielach zo súčasnosti občas spája s väčšou či menšou mierou dešpektu $\mathrm{k}$ postavám, ktoré ho nenadobudli. Tento dešpekt je vo výnimočných prípadoch miernený napríklad odkazmi na nerovnocenné zaobchádzanie pri prijímaní na vysoké školy, napr. pre zlé kádrové profily. To je prípad filmu Strelnica (réžia Miloslav Volný, 1990), v ktorom protagonista, znechutený vzdelanostnou úrovňou vojakov na základnej vojenskej službe, spoznáva chlapca, ktorý sa na univerzitu nedostal, a tak ju tajne navštevuje. Práve v uvedenom kontexte však môže pretrvávajúce bazírovanie na konflikte vysokoškolsky vzdelaných a tých „bez vzdelania“ byt' alarmujúce. Signalizuje strach z primitívneho správania, asociovaného s nedostatkom vzdelania. Napríklad vo filme Papierový drak čelí učitel' výtvarnej výchovy agresívnemu správaniu nevzdelaného suseda, ktorý je zhodou okolností otcom jeho talentovaného žiaka, a takmer v priamom prenose sleduje aj tragické následky tejto agresie, ked’ utýraný chlapec spácha samovraždu.

Význam vymedzovania a izolácie tvorivých profesií i variácie na tému ich ohrozenia sú teda v tvorbe raných devätdesiatych rokov pomerne rôznorodé. V niektorých prípadoch ide o naturalizované obrazy, ktoré predstierajú prirodzenost' zamerania na exkluzívne profesie (Jediná, Dve Anny). V d’alších je naturalizácia súčastou inscenovania cudzorodých prostredí, napr. prostredníctvom adaptácií diel zahraničných 
spisovatel’ov i diel z minulosti. Inokedy je profesijná exkluzivita súčast’ou znepokojenia z vítazstva pragmatizmu nad tvorivostou (Konečná dolina), či z pretrvávajúcej rigidnosti školského prostredia (Štyri pät’ky, réžia Kvetoslav Hečko, 1992; Papierový drak). Z času na čas sa vyskytne prípad výstižnej autoreflexívnej irónie namierenej do vlastných umeleckých radov (Mačka domáca), ba aj tragického sebaspytovania fatálnych zlyhaní, ktoré fungujú ako paralela k tým súčasným (Výstrel na Bonaparta, réžia Ján Zeman, 1992 - adaptácia novely Bulata Okudžavu o šlachticovi, ktorý sa v atmosfére mobilizácie proti imperátorovi nastolenému Francúzskou revolúciou pokúsi spáchat’ na vládcu atentát, aby zabránil krviprelievaniu). Niekedy sa dokonca namiesto povýšeneckého zdôrazňovania vzdelania pracuje s myšlienkou dobrovolného bláznovstva, ako napríklad vo filme Európa, moja láska (réžia Vido Horňák, 1992), posúvajúcom dej Pirandellovho Henricha $I V$. do doby po páde železnej opony. Bez ohl'adu na prístup i na mieru naturalizácie však mnohé diela pracujú s vyčleňovaním inteligencie, prípadne priamo umeleckých a spisovatel'ských profesií v kontexte podvedomej i vedomej signalizácie ohrozenia. $V$ televíznom filme raných devätdesiatych rokov môžeme ohrozenie vnímat’ priamo (napr. $\mathrm{v}$ témach konfrontácie s abstraktnou mocou, ale i s rôznymi „nečistými“ - nevzdelanými, netvorivými, skostnatenými skupinami) i nepriamo (v nesúlade anotácií s výslednými dielami či v súboji viacerých podôb čistého o pravdu).

$\mathrm{V}$ tomto kontexte zrejme neprekvapí, že téma súboja čistoty a nebezpečenstva je v skutočnosti aj témou filmov, ktoré sa nevenujú tradične ušllachtilým druhom umenia, ale tvorivost' umenia asociujú s „nečistým “ biznisom či „nečistou“ módou. Ohrozovanie čistoty rôznymi formami „nečistého“ je tu niekedy až priezračné. No kým Darinka vo filme Takmer ružový príbeh (réžia Juraj Jakubisko, 1990), trpiaca dedičnou chorobou zrážanlivosti krvi, zvítazí nad hrozbou vlastnej menštruácie (nečistej i doslova nebezpečnej ${ }^{33}$ ) a ukáže svetu, že aj populárna hudba môže byt' „čistá", niektoré mládežnícke filmy ešte vždy starostlivo varujú pred povrchnostou módy a skorumpovanostou komerčnej umeleckej sféry (Muzikál, réžia Zoro Laurinc st., 1993), zobrazujú lesk a atraktivitu prostredia módnych prehliadok, butikov a drahého oblečenia v kontexte prázdnoty života bez zaneprázdnených rodičov (Čo dievčatká nevedia, réžia Marta Gogálová, 1990), prípadne cez zasvätené obrazy sveta umelcov konfrontujú tému čistoty s témami korupcie, pokrytectva i priskorej promiskuity mladých. Napríklad vo filme Muzikál afektovaná divadelná režisérka s výzorom hippie (Marta Gogálová) hl'adá „niečo čisté“ v mladých adeptkách na hlavnú rolu vo svojom novom muzikáli, no v skutočnosti rýchlo odhaluje svoju manipulatívnu, pokryteckú tvár a zrádza vlastné (už iba navonok deklarované) hodnoty. Komerčnost', individualizmus mládeže a jej subkultúr, konzum a premenlivá móda patria teda medzi d’alšie oblasti, ktoré v umeleckých sférach ešte aj v raných devätdesiatych rokoch budili neistotu, priţahovali i odpudzovali zároveň, a minimálne od čias prestavby sa stretávali paralelne s odsudzovaním, no aj so snahami o akceptáciu či dokonca pochopenie. ${ }^{34}$

\footnotetext{
${ }^{33}$ Akonáhle polosirota Darinka príde do puberty, starostlivá teta ju zavrie do izby a nepúšta von. Jakubisko vo filme reinterpretuje rozprávku o Śípkovej Ruženke i dobové obavy z mládežníckych subkultúr práve prostredníctvom motívu Darinkinej choroby, ktorá - vo vnímaní tradične „nečistú" - menštruáciu robí doslova nebezpečnou pre hrdinku.

${ }^{34}$ Viac o rôznorodosti prístupov v kontexte postojov spisovatel'skej obce k individualizmu i (sub)kultúram mladých (vrátane ich záluby v zábavnom priemysle) pozri PULLMANN, Michal. Konec experimentu, s. $124-125$.
} 


\section{Záver}

Zameranie na tvorivé, umelecké a d’alšie elitné profesie vyžadujúce vysokoškolské vzdelanie bolo v audiovizuálnej produkcii prelomu osemdesiatych a devätdesiatych rokov zretel'né do takej miery, že napokon vyústilo do autokorekcií. Nemožno si ich nevšimnút napríklad v tvorbe Martina Šulíka, ktorý svoje postavy už na začiatku devätdesiatych rokov vracia aspoň k vidieckym „koreňom“. Do televíznej produkcie sa autokorekcie v zmysle výraznejšieho zaludnenia filmov zo súčasnosti postavami mimo kruhov inteligencie dostávali len vel'mi postupne, no v zásade sa - napríklad vd’aka projektom tvorcov sústredených okolo Radošinského naivného divadla - objavovali počas celého ponovembrového obdobia. Na začiatku nového milénia však už boli v televíznej tvorbe markantnejšie než v kinematografii. Spomeňme zrejme prvú slovenskú súčasnú „,sociálnu drámu“, televízny film Ticho Zuzany Liovej (2005), niektoré časti cyklu adaptácií klasických literárnych diel Nesmrtel’ni ${ }^{35}$ či cyklu Filmoviedky ${ }^{36}$. Kým sa však tak stalo, v hranej televíznej tvorbe rokov 1990 - 1993 popri sebe koexistovali romantické naratívy, v ktorých elity zvyčajne hrali (alebo zápasili o) úlohu iniciátorov spoločenskej zmeny, a skeptické naratívy, v ktorých sa elity umárali v sebaspytovaní i vzájomných šarvátkach, márne bojovali s autoritatívnou mocou i vlastnými ilúziami, alebo vyznačovali hranice svojho ohrozenia: hranice "čistého" (tvorivého, vzdelaného, l'udského, kultivovaného) a „nečistého“ (byrokratického, nevzdelaného/primitívneho, neludského, konzumného). Bez ohl'adu na to, či jednotlivé diela odkazujú na Nežnú revolúciu (alebo ju anticipujú), či boli pripravované pred Novembrom 1989 alebo až po ňom, dominuje v nich čosi, čo v širšom spoločenskom, politickom, mediálnom a kultúrnom kontexte môžeme vnímat’ ako diskurz prestavby. Predstavy o hraniciach medzi „čistým“ a „nečistým“ sú často vymedzované práve týmto diskurzom, jeho dôrazom na odmietanie byrokracie, plytvania, neefektívnosti, totalitných praktík, ale aj jeho výrazne zneisteným postojom ku konzumnej, resp. komerčnej kultúre, ktorý je plný akceptovania, fascinácie i strachu zároveň.

Štúdia je výstupom projektu VEGA č. 2/0120/18 Inštitucionálne, produkčné a koprodukčné vzt'ahy medzi verejnoprávnou televíziou a pôvodnou filmovou tvorbou po roku 1989.

\footnotetext{
${ }^{35}$ Cyklus bol založený na transferoch diel klasickej domácej i svetovej literatúry do súčasnosti, čo umožnilo zaujímavé presuny pozornosti na spoločenské vrstvy, ktoré v danej dobe neboli tak často tematizované ani v kinematografii. Napríklad vo filme Dlhá cesta domov (réžia Katarína Ďurovičová, 2010) je do prostredia súčasného malomestského sídliska prenesený dej Rysavej jalovice. Vystupuje v ňom plejáda postáv zahŕňajúca nezamestnaných, bezdomovcov, sezónnych robotníkov, predavačky v hypermarketoch, vrátnikov či predavačov v autobazári (a i.).

${ }^{36}$ Napr. Nočný trezor (réžia Karol Vosátko, 2011).
} 


\section{IMAGES OF ARTISTS IN TELEVISION NARRATIVES \\ OF THE VELVET REVOLUTION 1990 - 1993}

\section{Jana DUDKOVÁ}

The text is a partial result of the thematic analysis of Slovak television production from the early 1990s, which Slovak film studies has not yet fully examined. The author analyses the figure of an artist and/or humanistic intelligentsia in television fiction after November 1989, emphasising especially images of their exclusion in terms of "purity and danger" concepts as well within the context of sceptical narratives of the social change.

Jana Dudková

Ústav divadelnej a filmovej vedy CVU SAV

Dúbravská cesta 9

84101 Bratislava

e-mail: janadudkova@gmail.com 